\title{
Post-waterlogging Rescue Nitrogen Improves Waterlogging Tolerance in Mungbean (Vigna radiata)
}

\author{
Md. Rafiqul Islam ${ }^{1}{ }^{*}$, Mehfuz Hasan ${ }^{2}$, Munny Akter ${ }^{1}$ and Nazmun Nahar Shibly ${ }^{1}$ \\ ${ }^{1}$ Department of Agronomy and ${ }^{2}$ Department of Genetic and Plant Breeding, Bangabandhu Sheikh \\ Mujibur Rahman Agricultural University, Gazipur-1706, Bangladesh \\ *Corresponding author and Email: rafiarib@yahoo.com
}

Received: 03 November 2018

Accepted: 09 November 2019

\begin{abstract}
The study was conducted at the Stress Research Site of the Department of Agronomy of Bangabandhu Sheikh Mujibur Rahman Agricultural University, Gazipur, Bangladesh during the period from April to July 2017 to evaluate the effect of rescue nitrogen fertilizer for improving the performance of waterlogging tolerance in mungbean genotype VC-6173A. Both waterlogged and non-waterlogged mungbean plants were received varying doses of rescue nitrogen from urea fertilizer. The rescue nitrogen $(\mathrm{N})$ treatments were: $\mathrm{N}_{0}$-no rescue $\mathrm{N} ; \mathrm{N}_{30}-20$ and $10 \mathrm{~kg} \mathrm{ha}^{-1}$ rescue $\mathrm{N}$ applied at 0 -day and 15-day after removal of waterlogging (ARW); $\mathrm{N}_{40}-30$ and $10 \mathrm{~kg} \mathrm{ha}^{-1}$ rescue $\mathrm{N}$ applied at 0-day and 15-day ARW and $\mathrm{N}_{50}-40$ and $10 \mathrm{~kg} \mathrm{ha}^{-1}$ rescue $\mathrm{N}$ applied at 0-day and 15-day ARW. The study was laid out in a randomized complete block design with four replications. Different levels of rescue $\mathrm{N}$ improved plant height, leaf chlorophyll index, phonological period, plant growth, pod formation and seed yield of mungbean. N-treated plants showed higher relative SPAD chlorophyll values and the increment was higher for higher $\mathrm{N}$-dose. Waterlogging reduced $40 \%$ root dry matter and $34 \%$ both shoot and total dry matter relative to non-waterlogged plants. Rescue $\mathrm{N}$ significantly increased both the root and shoot dry matter. The waterlogged plants without rescue $\mathrm{N}$ showed $29 \%$ reduction in the number of pods per plant and the reduction showed $13 \%$ for rescue $\mathrm{N}_{40}$ in waterlogged plants. The seed yield reduction was $25 \%$ in waterlogged plants without rescue $\mathrm{N}$ but with rescue $\mathrm{N}$, seed yield remarkably increased particularly in $\mathrm{N}_{40}$-treated plants. Therefore, the study suggests that rescue $\mathrm{N}$ fertilizer application may be a viable practice in improving waterlogging tolerance and increasing yield of mungbean.
\end{abstract}

Keywords: Mungbean, waterlogging, nitrogen fertilization, root and shoot growth, seed yield.

\section{Introduction}

Mungbean (Vigna radiata L.Wilczek) is one of the popular pulse crops of Bangladesh. It is rich in digestible protein (approximately 25-28\%) and extensively grown in tropical and subtropical Asia because of its wider range of adaptability
(Kumar et al., 2013). In Bangladesh, more than one lac hectare of land is covered by mungbean cultivation (BBS, 2017). The farmers of the country prefer mungbean cultivation mainly because of the rapid growth and early maturity, and its ability to fit well in rice-based cropping systems. Mungbean yield in Bangladesh is 
generally low due to many reasons. Different abiotic stresses are the major ones. Among the abiotic stresses, waterlogging stress is most common and restricts mungbean production, particularly when the waterlogging is encountered at the early stage of crop growth (Singh and Singh, 2011).

Waterlogging reduces oxygen concentrations around the roots of the waterlogged plants and limits nodulation and nitrogen fixation. The uptake of major nutrients ( $\mathrm{N}, \mathrm{P}$ and $\mathrm{K}$ ) is also hampered (Elzenga and van Veen, 2010). Waterlogging results in a severe reduction in nutrient concentrations and leaching of nitrogen beyond the root zone and the plants suffer from nitrogen deficiency (Kisaakye et al., 2017; Steffens et al., 2005). Such deficiency is associated with the limited root activities and yellowing of leaves (Habibzadeh et al., 2013). The denitrification of nitrate ions and rapid volatilization in waterlogged soil may also cause nitrogen deficiency (Rasaei et al., 2012). Therefore, waterlogged soils need to maintain its fertility cautiously for sustainable crop production (Bhaduri et al., 2017).

The supply of nutrients and its availability in the soil plays a significant role in waterlogging tolerance of plants (Romheld and Kirkby, 2010). The major adaptive mechanism of plants to waterlogging is the production of adventitious roots during the post-flooding period (Islam et al., 2010). The development of such adventitious roots may be enhanced and accelerated through $\mathrm{N}$ application (Kaur et al. 2017; Ren et al., 2017). As a result, oxygen supply may increase and plants can recover quickly from flooding injury. Exogenously applied nitrogen fertilizer following waterlogging was found to improve the growth and development of corn and soybean (Kaur et al., 2018; Kaur et al., 2017), maize and wheat (Zheng et al., 2017) and cotton (Ashraf et al., 2011). Application of nitrogen to pastures just before they become waterlogged was found effective (McFarlane and Glencross, 1994). It was reported that the applied nitrate may enter anaerobically in damaged roots of waterlogged plants by passive means and translocated to the shoot (Trought and Drew, 1980). The use of $\mathrm{N}$ fertilizer can improve the crop root and shoot growth under soil-waterlogged conditions (Wu et al., 2013a, 2014) and the enhanced crop $\mathrm{N}$ uptake from urea top-dressed is likely to benefit grain quality, especially protein (Harris et al. 2016).

Nitrogen fertilization and some other management options were advocated by various scientists to overcome waterlogging stress in wheat (Hossain and Uddin, 2011), barley and oats (Setter and Waters, 2003) and maize (Zaidi et al., 2007) but such studies on mungbean are limited. Nitrogen applied waterlogged plants may retain more leaf area that can eventually accelerate the gas exchange processes. As a result, the waterlogged plants may produce a greater number of pods and finally increase the yield. Therefore, the study was carried out to assess the effectiveness of rescue nitrogen in improving waterlogging tolerance and yield of mungbean.

\section{Materials and Methods}

\subsection{Experimental site and soil}

The study was conducted at the Stress Research Site of the Department of Agronomy of Bangabandhu Sheikh Mujibur Rahman Agricultural University, Gazipur, Bangladesh from April to July 2017. The topsoil was manmade having silt loam in texture with shallow red brown terrace subsoil designated as Salna soil series under Madhupur Tract (AEZ 28). The chemical properties are characterized by slightly acidic in reaction with very low and low contents of nitrogen and phosphorus, respectively. The rainfall was intermittent during the experimentation and a substantial rainfall occurred when waterlogging treatments were imposed. However, there was very low rainfall at the time of rescue $\mathrm{N}$ application but a heavy rainfall occurred just before a second application of rescue N. After 65 DAE, it started heavy rains and continued until termination of the experimentation. The maximum temperature 
ranged between 30.1 and $33.1^{\circ} \mathrm{C}$ and did not vary significantly during the crop growing period, but minimum temperature progressively increased from 23.4 to $27.1^{0} \mathrm{C}$ (Figure 1 ).

\subsection{Treatment, layout and experimental design} A waterlogging tolerant mungbean genotype VC-6173A was used in the study. Two types of soil conditions were created viz. no-waterlogging (control) and waterlogging and both were applied with urea @ $40 \mathrm{~kg} \mathrm{ha}{ }^{-1}$, triple superphosphate@85 kg ha ${ }^{-1}$, muriate of potash @ $35 \mathrm{~kg} \mathrm{ha}^{-1}$ and cowdung @ 10 t/ha (blanket dose) during final land preparation. Four doses of rescue nitrogen were applied in both waterlogged and non-waterlogged plants after imposing waterlogging treatments. The rescue nitrogen $(\mathrm{N})$ treatments were: $\mathrm{N}_{0}$-no rescue $\mathrm{N}$; $\mathrm{N}_{30}$ - rescue $\mathrm{N}$ at $30 \mathrm{~kg} \mathrm{ha}^{-1}$ of which $20 \mathrm{~kg} \mathrm{ha}^{-1}$ applied at 0-day ARW (30 DAE) and $10 \mathrm{~kg} \mathrm{ha}^{-1}$ at 15-day ARW (45 DAE); $\mathrm{N}_{40}-$ rescue $\mathrm{N}$ at 40 $\mathrm{kg} \mathrm{ha}^{-1}$ of which $30 \mathrm{~kg} \mathrm{ha}^{-1}$ applied at 0-day ARW (30 DAE) and $10 \mathrm{~kg} \mathrm{ha}^{-1}$ at 15-day ARW (45 DAE) and $\mathrm{N}_{50}$ - rescue $\mathrm{N}$ at $50 \mathrm{~kg} \mathrm{ha}^{-1}$ of which $40 \mathrm{~kg} \mathrm{ha}^{-1}$ applied at 0-day ARW (30 DAE) and $10 \mathrm{~kg} \mathrm{ha}^{-1}$ at 15 -day ARW (45 DAE). The size of the experimental unit plot was $1.2 \times 1.0 \mathrm{~m}$ and the total number of plots was 32 . The spacing between the waterlogged and control plots was $1.5 \mathrm{~m}$ to avoid side entry of seepage water to the control plots. Polythene sheets were used in waterlogged treatments to avoid side leakage of water. The treatments were arranged in a randomized complete block design with four replications.

\subsection{Land preparation and management practices}

The experimental plots were prepared by plowing and cross plowing. Seeds of uniform size and shape were sown on 3 April 2017 after treated with Provex 200 at $3 \mathrm{~g} / \mathrm{kg}$ seed. Line to line and plant to plant distance were maintained 30 and $10 \mathrm{~cm}$, respectively. Seedlings were emerged within 3-4 days after sowing. After thinning, one health seedling was kept for maintaining the plant to plant distance. The experimental plots were kept totally weed free from 15 DAE to 30 DAE. Insecticide Karate at 2 $\mathrm{ml} / \mathrm{L}$ was applied two times maintaining intervals of 10 days at the vegetative stage, and once at the pod-filling stage for controlling thrips and pod borers. A single heavy irrigation was done just after seeding and thereafter, irrigation water was applied only when it was required.

\subsection{Imposition of waterlogging stress}

Waterlogging treatment was imposed to 25-day old seedlings and flooding depth was maintained $2-3 \mathrm{~cm}$ for three days. After removal of waterlogging, soils remained at saturation conditions for two days and altogether five days (25-30 DAE) were considered as waterlogging period. At the same time, the optimal soil moisture was maintained in plants retained as control. Rescue $\mathrm{N}$ fertilizer doses were applied once at the removal of waterlogging (30 DAE) and another at 15 days after removal of waterlogging (45 DAE) (Figure 1).

\subsection{Data collection}

Data on plant height, SPAD (Soil-Plant Analysis Development) chlorophyll index, dry matter production, and yield components were recorded for both waterlogged and non-waterlogged control plants applied with or without rescue $\mathrm{N}$ treatments. For this, five plants from each treatment were selected for recording the data.

\subsubsection{Plant height}

Periodic plant height for both waterlogged and non-waterlogged plants was measured starting from 6 days after waterlogging (DAW) with three days interval up to $18 \mathrm{DAW}$. Individual plant height was measured from the base at the ground level to the top of the main shoot.

\subsubsection{SPAD chlorophyll value}

SPAD chlorophyll value/index was recorded three days interval starting from 6 DAW up to 18 DAW or both waterlogged and non-waterlogged plants. A portable chlorophyll meter (Minolta SPAD 502) was used for recording SPAD chlorophyll value of leaves. SPAD value was measured at proper sunlight just prior to harvesting the plants at field conditions. 


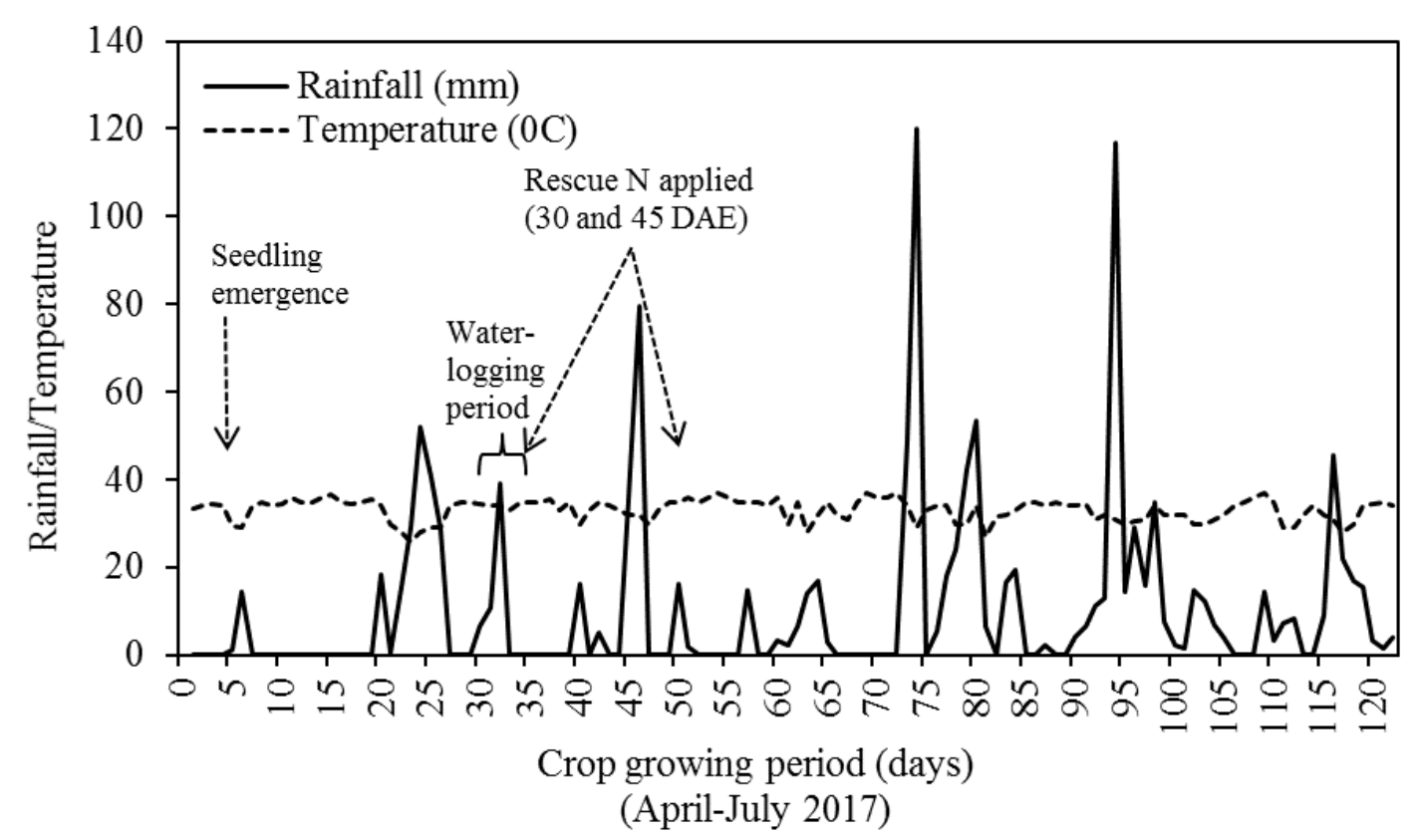

Figure 1. Trends of rainfall and maximum temperature during crop growing period

\subsubsection{Dry matter production}

Five plants from both waterlogged and nonwaterlogged plots were harvested at 3-weeks after removal of waterlogging to determine the dry weight (DW) of different plant parts. After harvesting, plants were segmented into different components (root, stem, petiole and leaf). The segmented parts were then dried in an oven at $80^{\circ} \mathrm{C}$ for 72 hours until a constant weight achieved and then the dry weight was recorded. Total DW was estimated by summing up the DW of root, stem, petiole and leaf and that of shoot DW by excluding root DW from the total DW.

\subsubsection{Phenological characters}

Phenological data i.e. days to first flowering, days to $50 \%$ flowering and days to maturity were recorded from the middle row of each experimental plot. Days to first flowering were counted when at last one flower was opened in a plot. Days to $50 \%$ flowering was counted when $50 \%$ of plants of each treatment plot have at least one opened flower. Days to maturity was considered when about $80 \%$ of pods showed physiological maturity.

\subsubsection{Pod and seed yield}

Plants were harvested at variable dates depending on maturity duration and treatments, and the yield parameters such as the number of pod/plant and seed yield were recorded. For this, both waterlogged and non-waterlogged plants were uprooted carefully by hand and then bundled and tagged. Thereafter, pods were threshed carefully in the laboratory and kept them under the open sunlight for drying. When the pod walls became brittle, the seed and straw were separated, cleaned and then dried under sunlight for desirable moisture level. Pods from selected five plants were harvested when $95 \%$ pods were matured and weighted after sundry to maintain moisture level $12 \%$.

\subsection{Statistical analysis}

The data of all treatments were subjected analyzed statistically by using software Statistix 
10 (Analytical software, 2018). All the recorded data were analyzed using analysis of variance (ANOVA) and means were compared by using Least Significant Difference (LSD) test at a significance level of $P \leq 0.05$.

\section{Results and Discussion}

\subsection{Plant height}

The plant height of mungbean increased with the increasing age of plants in non-waterlogged control plants. A similar trend was also observed in waterlogged plants treated with or without rescue $\mathrm{N}$ but plant height significantly decreased in waterlogged plants applied with or without rescue $\mathrm{N}$ compared to non-waterlogged plants (Figure 2). Higher the $\mathrm{N}$ dose lower was the plant height. This indicates that $\mathrm{N}$ fertilizer depressed the plant height of waterlogged plants. However, when height growth was compared as a relative value between control plants and waterlogged plants with or without rescue $\mathrm{N}$ application, the scenarios are different (Figure 2 ). The relative values of different doses of rescue $\mathrm{N}$ applied plants significantly increased at 9 days after rescue $\mathrm{N}$ application (DRN).
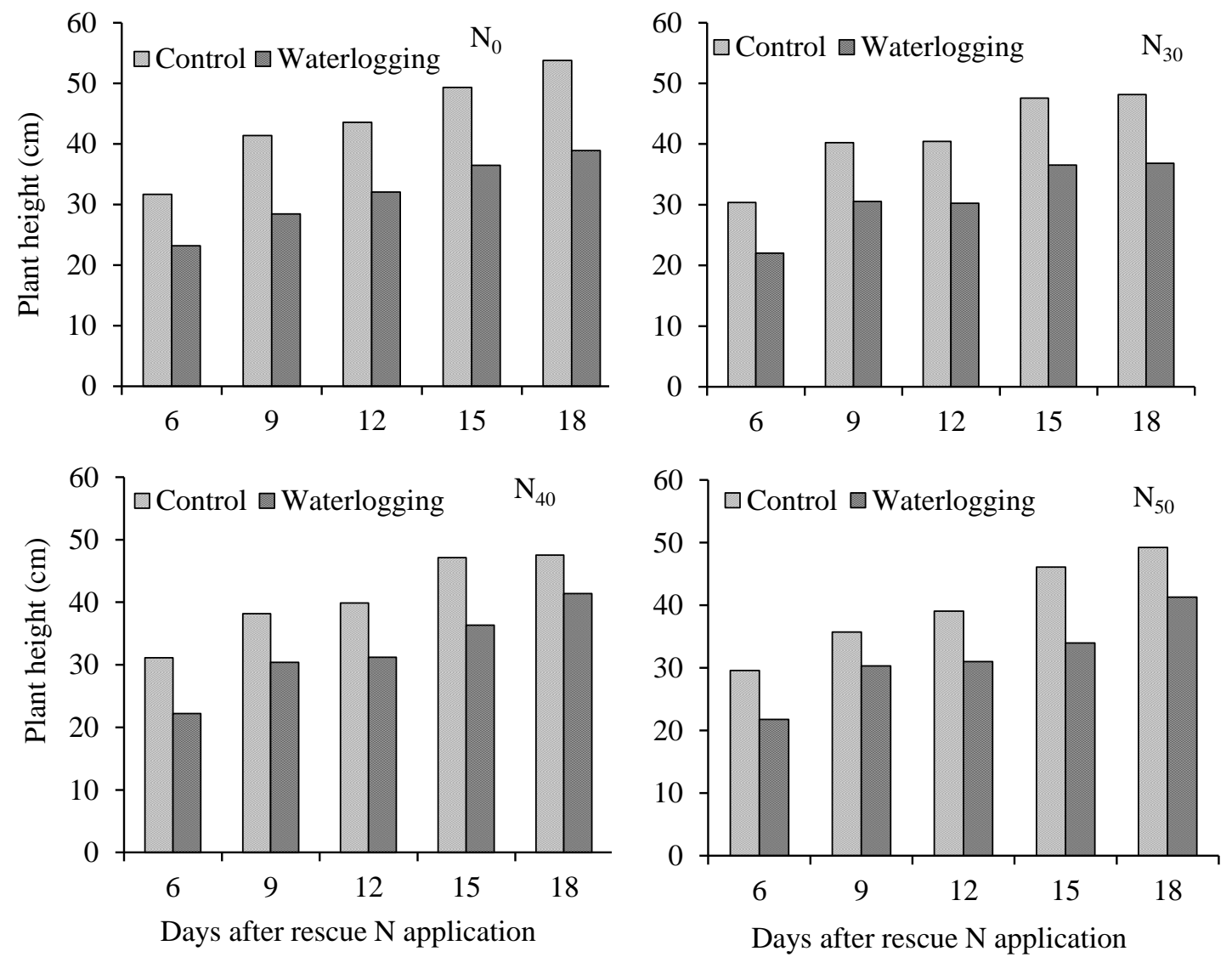

Figure 2. The response of plant height in mungbean applied with varying rate of rescue nitrogen under non-waterlogged and waterlogged conditions. 


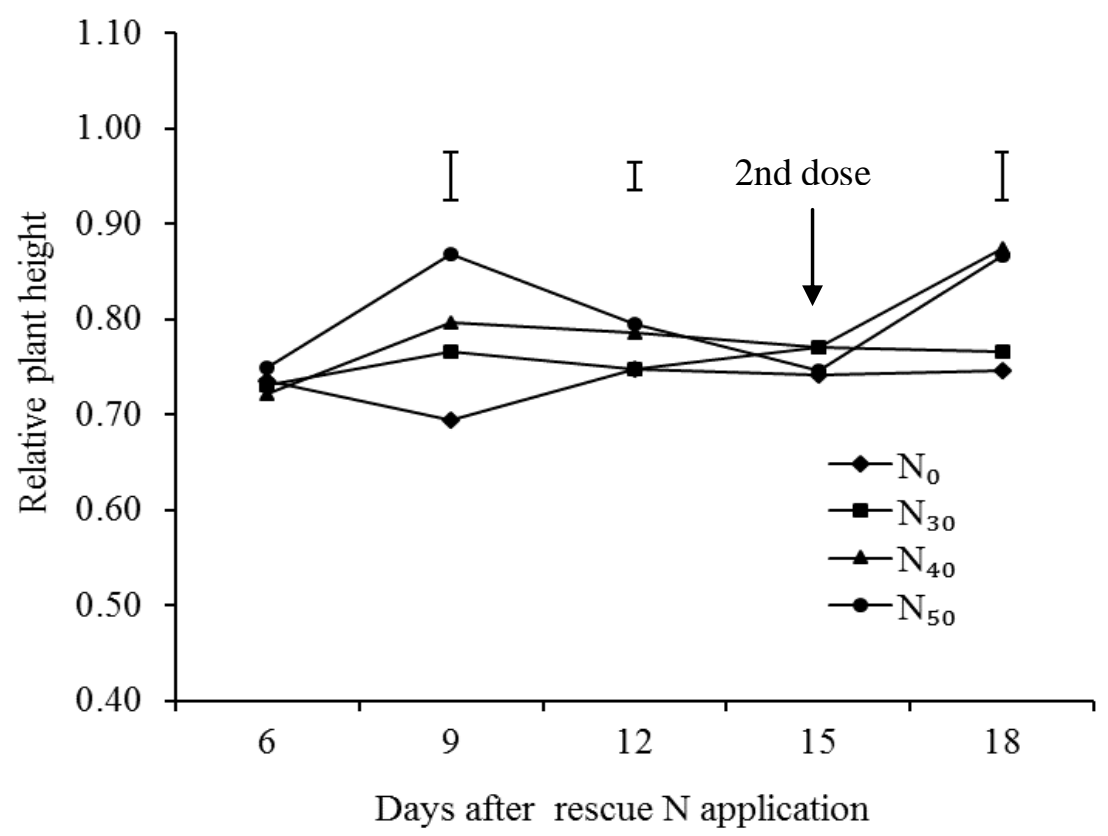

Figure 3. Relative plant height of mungbean applied with varying rates of rescue nitrogen under nonwaterlogged and waterlogged conditions. Vertical bars indicate the mean difference values according to LSD at $\mathrm{P}<0.05$.

Thereafter, the values decreased but remained significantly higher compared to $\mathrm{N}_{0}$ and $\mathrm{N}_{30}$ treated plants at $12 \mathrm{DRN}$. The relative plant height again started to increase after second dose rescue $\mathrm{N}$ application particularly in $\mathrm{N}_{40}$ and $\mathrm{N}_{50}$ treatments. A significantly higher relative plant height in both these treatments indicated that plant height increment is associated with the amount of rescue $\mathrm{N}$ used. Tariq et al. (2001) observed that the application of $\mathrm{P}$ and $\mathrm{K}$ along with $\mathrm{N}$ increased plant height and number of branches plant ${ }^{-1}$.

\subsection{SPAD chlorophyll value}

The SPAD chlorophyll values were not consistent throughout the time of observation in both non-waterlogged and waterlogged plants with or without rescue nitrogen (Figure 4). Irrespective of treatments, the highest chlorophyll contents were observed at 9 DRN. In most cases, waterlogged plants applied with or without rescue $\mathrm{N}$ showed lower SPAD values up to $9 \mathrm{DRN}$, thereafter the values increased significantly. Interestingly, the rate of increase was as high as the values became greater than non-waterlogged plants. The lower SPAD values in waterlogged plants were commonly observed in many studies. It was noticed that the major cause of chlorophyll destruction is the formation of superoxide radicals under waterlogging situations (Malik et al., 2002; De Souza et al. 2011).

For a clear understanding, the relative SPAD values were computed that showed increasing trends with the advance of plant age irrespective of treatments (Figure 4). Rescue N-treated plants showed higher relative SPAD value compared to the plants applied without rescue $\mathrm{N}$, but varied remarkably between levels of rescue N. There were significant increases in relative SPAD values up to $12 \mathrm{DRN}$ and thereafter increment was not remarkable. After the second dose of $\mathrm{N}$ application, the relative SPAD values again 
increased which indicates a positive response of $\mathrm{N}$ to waterlogged plants. The most remarkable observation is that high dose of rescue $\mathrm{N}\left(\mathrm{N}_{50}\right)$ consistently maintained higher relative SPAD values. When medium dose $\left(\mathrm{N}_{40}\right)$ applied, waterlogged plants responded slowly after the first dose but a greater response was observed after second dose of rescue N. However, relative SPAD value dramatically increased for low rescue nitrogen $\left(\mathrm{N}_{30}\right)$ level, thereafter values decreased indicating rescue $\mathrm{N}$ might have been utilized by the plants within two weeks of its application and further addition of $\mathrm{N}$ did not improve SPAD value. On the other hand, the relative increment of SPAD value continued in plants applied with $\mathrm{N}_{40}$ and $\mathrm{N}_{50}$ levels of rescue $\mathrm{N}$. Application of additional $\mathrm{N}$ fertilizer in waterlogged plants from various sources resulted in higher SPAD values compared to nonwaterlogged plants in maize (Kaur et al., 2018). Nitrogen fertilizer applied as liquid form maintained chlorophyll levels either equal to or greater than that of the foliar and broadcasting (Reed and Gordon, 2005).
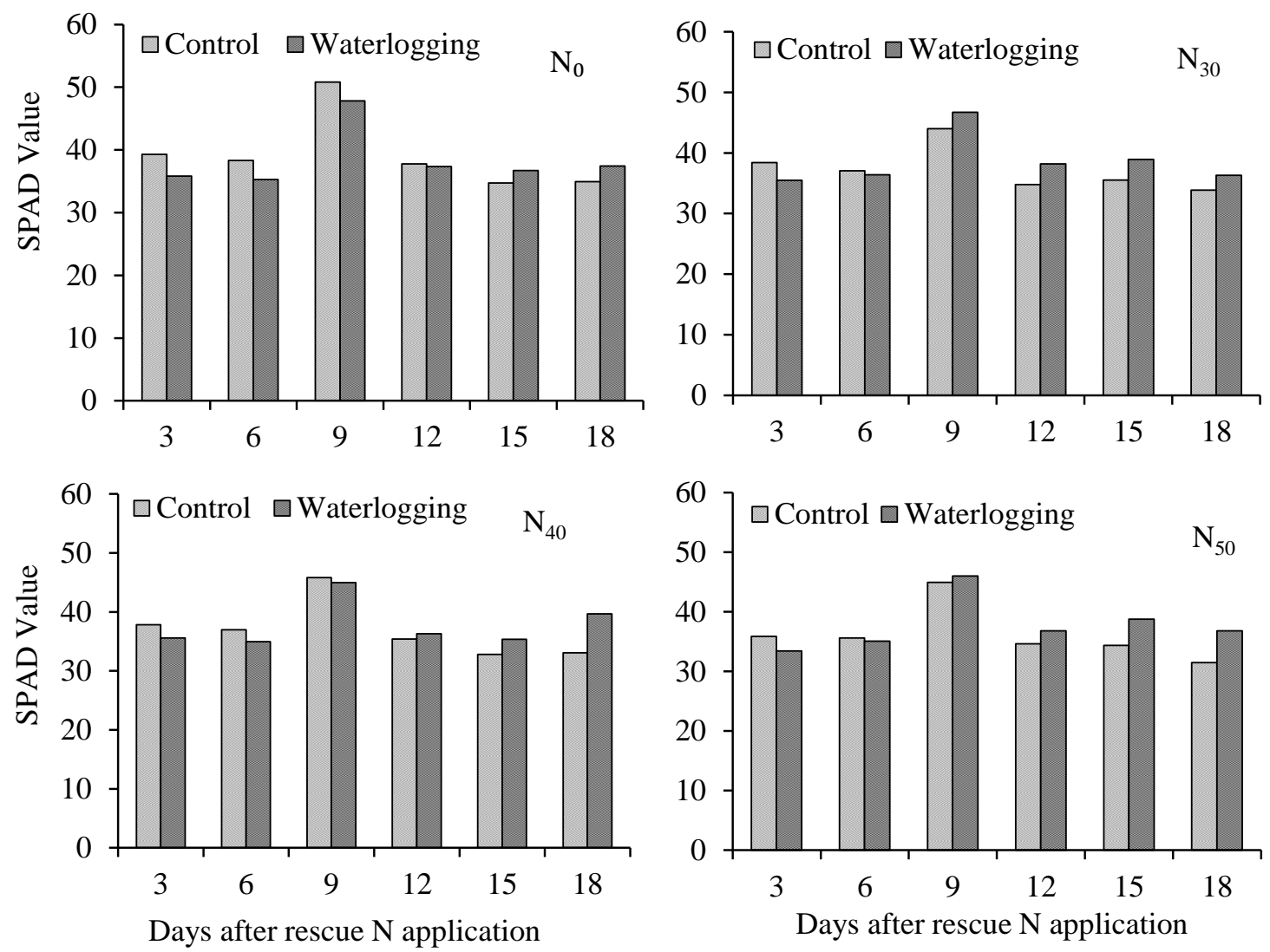

Figure 4. The response of SPAD chlorophyll value of leaves in mungbean applied with varying rate of rescue nitrogen under non-waterlogged and waterlogged conditions. 


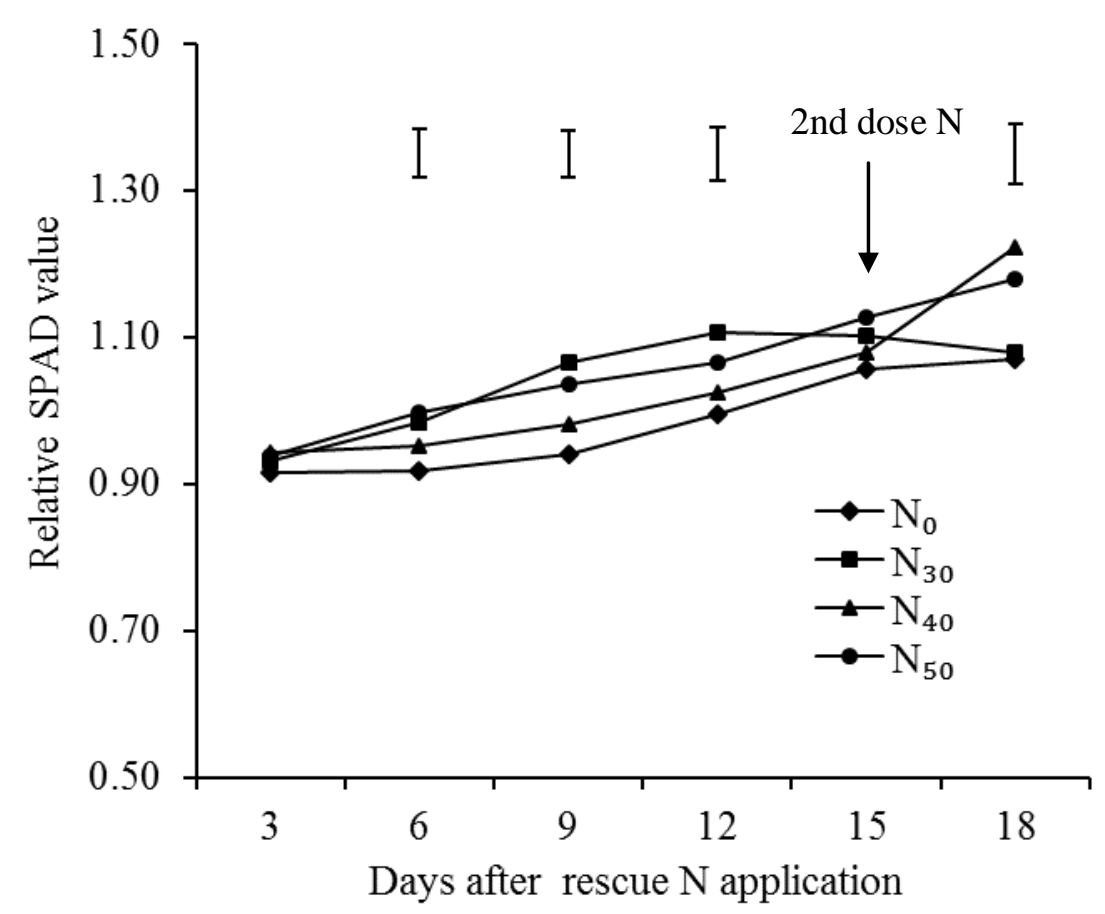

Figure 5. Relative SPAD chlorophyll values of leaves in mungbean applied with varying rates of rescue nitrogen under non-waterlogged and waterlogged conditions. Vertical bars indicate the mean difference values according to LSD at $\mathrm{P}<0.05$.

\subsection{Root and shoot development}

Effect of post-waterlogging rescue $\mathrm{N}$ fertilizer on the dry matter production root, shoot and total plant in mungbean are illustrated in Table 1. Relative root dry matter significantly decreased due to waterlogging showing $40 \%$ reduction relative to non-waterlogging when rescue $\mathrm{N}$ was not applied. Such reduction ranged from $27-29 \%$ when different doses of rescue $\mathrm{N}$ applied in waterlogged plants. However, rescue $\mathrm{N}$ application had a little tendency to increase the root dry matter with increasing $\mathrm{N}$ doses. Guo et al. (2010a) reported that $\mathrm{N}$ fertilization just after waterlogging enhanced root development that contributed to waterlogging tolerance in cotton. In this study, we applied rescue $\mathrm{N}$ two times i.e. just after removal of waterlogging (ARW) and 15 days ARW. The research results in Western Australia showed that $\mathrm{N}$ recovery was minimal when applied just ARW but recovery increased greatly when applied three-weeks ARW (Paterson and Palta, 2007).

The shoot dry matter also decreased largely due to waterlogging without rescue nitrogen and showed a $36 \%$ reduction based on relative values when compared with non-waterlogged control plants. However, the application of rescue nitrogen in both non-waterlogged and waterlogged plants decreased shoot dry matter. The higher relative values indicate that reduction of shoot dry weight decreased with the increase in $\mathrm{N}$ dose, where $\mathrm{N}_{30}, \mathrm{~N}_{40}$ and $\mathrm{N}_{50}$ doses showed 23, 18 and $12 \%$ reduction in shoot dry weight, respectively. In canola, waterlogging stress was also found to depress shoot and root growth and such adverse effects of waterlogging were alleviated by foliar application of nitrogen 
compounds (Habibzadeh et al., 2013). However, they emphasized on the appropriate amount and timely application of $\mathrm{N}$ fertilizer during the recovery phase in cotton. An appropriate amount may increase waterlogging resistance by altering the antioxidant enzyme activities of the root, reducing lipid peroxidation and boosting root vigor (Guo et al., 2010b).

Similarly, the relative total dry matter decreased by $34 \%$ in waterlogged plants without rescue nitrogen. The relative values indicate that reduction of total plant dry weight decreased with the increase of rescue $\mathrm{N}$ doses as observed in shoot dry matter. This indicates that additional $\mathrm{N}$ fertilizer enhanced dry matter accumulation in waterlogged plants. The growth improvement due to $\mathrm{N}$ fertilizer application in cotton seedlings affected by waterlogging was also observed by Zhou and Oosterhuis (2012). Sigua et al. (2012) noticed that some forage species have the ability to recover from waterlogging injury by increasing dry matter production. They also found that this increase was linearly related to the increasing amount of $\mathrm{N}$ fertilizer. Other findings suggested that there were beneficial effects of all tested nitrogen compounds on the growth and biochemical attributes under waterlogged conditions (Jain et al., 2016).

\subsection{Duration of flowering and maturity}

In general, flower initiation delayed in waterlogged plants compared to nonwaterlogged control plants. The relative value of days to first flowering indicates that application of rescue nitrogen had a very little effect on days to first flowering (Table 2). Similar results were also observed for days to $50 \%$ flowering, although there was a tendency to increase days to $50 \%$ flowering with the increase of rescue nitrogen doses. However, maturity duration delayed for medium $\mathrm{N}$ dose $\left(\mathrm{N}_{2}\right)$. Amin et al. (2015) reported that soil waterlogging delayed flowering but the application of $\mathrm{N}$ and $\mathrm{K}$ fertilizers after the termination of waterlogging enhanced early flowering by 4 to 6 days compared to that of control.

Table 1. Effect of $\mathrm{N}$ fertilizer on the dry matter production of root, shoot and total plant in waterlogged mungbean

\begin{tabular}{|c|c|c|c|c|c|c|c|c|c|}
\hline \multirow[t]{2}{*}{ Treatment } & \multicolumn{2}{|c|}{$\begin{array}{l}\text { Root DW } \\
\text { (g/plant) }\end{array}$} & \multirow{2}{*}{$\begin{array}{c}\text { Relative } \\
\text { root } \\
\text { DW }\end{array}$} & \multicolumn{2}{|c|}{$\begin{array}{l}\text { Shoot DW } \\
\text { (g/plant) }\end{array}$} & \multirow{2}{*}{$\begin{array}{c}\text { Relative } \\
\text { shoot } \\
\text { DW }\end{array}$} & \multicolumn{2}{|c|}{$\begin{array}{c}\text { Total DW } \\
\text { (g/plant) }\end{array}$} & \multirow{2}{*}{$\begin{array}{c}\text { Relative } \\
\text { total } \\
\text { plant } \\
\text { DW }\end{array}$} \\
\hline & $\mathrm{C}$ & $\mathrm{W}$ & & $\mathrm{C}$ & $\mathrm{W}$ & & $\mathrm{C}$ & $\mathrm{W}$ & \\
\hline $\mathrm{N}_{0}$ & $\begin{array}{c}0.82 \\
\pm 0.07\end{array}$ & $\begin{array}{c}0.49 \\
\pm 0.03\end{array}$ & $0.60 \mathrm{~b}$ & $\begin{array}{l}11.51 \\
\pm 0.47\end{array}$ & $\begin{array}{c}7.38 \\
\pm 0.19\end{array}$ & $0.64 c$ & $\begin{array}{l}12.34 \\
\pm 0.53\end{array}$ & $\begin{array}{c}7.87 \\
\pm 0.16\end{array}$ & $0.64 c$ \\
\hline $\mathrm{N}_{30}$ & $\begin{array}{c}0.65 \\
\pm 0.04\end{array}$ & $\begin{array}{c}0.46 \\
\pm 0.02\end{array}$ & $0.71 \mathrm{a}$ & $\begin{array}{c}8.45 \\
\pm 0.12\end{array}$ & $\begin{array}{c}6.51 \\
\pm 0.26\end{array}$ & $0.77 b$ & $\begin{array}{c}9.10 \\
\pm 0.13\end{array}$ & $\begin{array}{c}6.97 \\
\pm 0.24\end{array}$ & $0.77 b$ \\
\hline $\mathrm{N}_{40}$ & $\begin{array}{c}0.68 \\
\pm 0.08\end{array}$ & $\begin{array}{c}0.50 \\
\pm 0.0 .02\end{array}$ & $0.73 a$ & $\begin{array}{c}7.73 \\
\pm 0.37\end{array}$ & $\begin{array}{l}6.52 \\
\pm 33\end{array}$ & $0.84 a$ & $\begin{array}{l}8.42 \\
\pm 30\end{array}$ & $\begin{array}{c}7.01 \\
\pm 0.31\end{array}$ & $0.83 a$ \\
\hline $\mathrm{N}_{50}$ & $\begin{array}{c}0.73 \\
\pm 0.03\end{array}$ & $\begin{array}{c}0.54 \\
\pm 0.03\end{array}$ & $0.73 a$ & $\begin{array}{c}8.48 \\
\pm 0.28\end{array}$ & $\begin{array}{c}7.46 \\
\pm 0.16\end{array}$ & $0.88 \mathrm{a}$ & $\begin{array}{c}9.21 \\
\pm 0.30\end{array}$ & $\begin{array}{c}8.00 \\
\pm 0.14\end{array}$ & $0.87 \mathrm{a}$ \\
\hline $\begin{array}{l}\text { LSD } \\
\text { CV }\end{array}$ & & & $\begin{array}{c}0.042 \\
5.78\end{array}$ & & & $\begin{array}{c}0.044 \\
3.51\end{array}$ & & & $\begin{array}{c}0.064 \\
3.40\end{array}$ \\
\hline
\end{tabular}

Note: $\mathrm{N}_{0}$-no rescue $\mathrm{N} ; \mathrm{N}_{30}, \mathrm{~N}_{40}$ and $\mathrm{N}_{50}$ - rescue $\mathrm{N}$ at 30,40 and $50 \mathrm{~kg} \mathrm{ha}^{-1}$, respectively; C-control and $\mathrm{W}$ waterlogging; Means followed by the same letter (s) are not significantly different at $\mathrm{P}<0.05$ by LSD; \pm Standard deviation. 
Table 2. Effect of rescue $\mathrm{N}$ fertilizer on the phenology of waterlogged mungbean plants

\begin{tabular}{|c|c|c|c|c|c|c|c|c|c|}
\hline \multirow[t]{2}{*}{$\begin{array}{l}\text { Treat- } \\
\text { ment }\end{array}$} & \multicolumn{2}{|c|}{$\begin{array}{l}\text { Days to first } \\
\text { flowering } \\
\text { (DFF-1) }\end{array}$} & \multirow[t]{2}{*}{$\begin{array}{c}\text { Relative } \\
\text { value of } \\
\text { DFF-1 }\end{array}$} & \multicolumn{2}{|c|}{$\begin{array}{l}\text { Days to } 50 \% \\
\text { flowering } \\
\text { (DFF-2) }\end{array}$} & \multirow[t]{2}{*}{$\begin{array}{c}\text { Relative } \\
\text { value of } \\
\text { DFF-2 }\end{array}$} & \multicolumn{2}{|c|}{$\begin{array}{l}\text { Days to maturity } \\
\text { (DM) }\end{array}$} & \multirow[t]{2}{*}{$\begin{array}{c}\text { Relative } \\
\text { value of } \\
\text { DM }\end{array}$} \\
\hline & $\mathrm{C}$ & W & & $\mathrm{C}$ & W & & $\mathrm{C}$ & $\mathrm{W}$ & \\
\hline $\mathrm{N}_{0}$ & $\begin{array}{c}32.5 \\
\pm 0.58\end{array}$ & $\begin{array}{c}34.3 \\
\pm 0.50\end{array}$ & 1.05 & $\begin{array}{c}40.5 \\
\pm 0.58\end{array}$ & $\begin{array}{c}41.0 \\
\pm 0.82\end{array}$ & 1.01 & $\begin{array}{c}52.5 \\
\pm 0.58\end{array}$ & $\begin{array}{c}54.8 \\
\pm 0.50\end{array}$ & $1.05 \mathrm{ab}$ \\
\hline $\mathrm{N}_{30}$ & $\begin{array}{c}32.0 \\
\pm 1.16\end{array}$ & $\begin{array}{c}34.0 \\
\pm 1.16\end{array}$ & 1.06 & $\begin{array}{c}40.3 \\
\pm 0.50\end{array}$ & $\begin{array}{c}40.3 \\
\pm 0.50\end{array}$ & 1.00 & $\begin{array}{c}53.0 \\
\pm 1.15\end{array}$ & $\begin{array}{c}54.0 \\
\pm 0.00\end{array}$ & $1.02 \mathrm{~b}$ \\
\hline $\mathrm{N}_{40}$ & $\begin{array}{c}33.0 \\
\pm 0.82\end{array}$ & $\begin{array}{c}34.0 \\
\pm 1.16\end{array}$ & 1.03 & $\begin{array}{c}39.5 \\
\pm 0.58\end{array}$ & $\begin{array}{c}40.5 \\
\pm 1.29\end{array}$ & 1.03 & $\begin{array}{c}52.0 \\
\pm 0.00\end{array}$ & $\begin{array}{c}55.3 \\
\pm 0.96\end{array}$ & $1.07 \mathrm{a}$ \\
\hline $\mathrm{N}_{50}$ & $\begin{array}{c}34.0 \\
\pm 0.82\end{array}$ & $\begin{array}{c}35.0 \\
\pm 0.00\end{array}$ & 1.02 & $\begin{array}{c}39.5 \\
\pm 0.58\end{array}$ & $\begin{array}{c}41.0 \\
\pm 1.16\end{array}$ & 1.04 & $\begin{array}{c}53.8 \\
\pm 0.96\end{array}$ & $\begin{array}{c}55.5 \\
\pm 0.58\end{array}$ & $1.04 \mathrm{~b}$ \\
\hline $\begin{array}{l}\text { LSD } \\
\mathrm{CV}\end{array}$ & & & $\begin{array}{c}\mathrm{NS} \\
2.09\end{array}$ & & & $\begin{array}{c}\text { NS } \\
2.78\end{array}$ & & & $\begin{array}{l}0.03 \\
1.75\end{array}$ \\
\hline
\end{tabular}

Note: $\mathrm{N}_{0}$-no rescue $\mathrm{N} ; \mathrm{N}_{30}, \mathrm{~N}_{40}$ and $\mathrm{N}_{50}$ - rescue $\mathrm{N}$ at 30,40 and $50 \mathrm{~kg} \mathrm{ha}{ }^{-1}$, respectively; C-control and $\mathrm{W}$ waterlogging; Means followed by the same letter (s) are not significantly different at $\mathrm{P}<0.05$ by LSD; \pm Standard deviation.

\subsection{Pod formation and seed yield}

Waterlogged plants without rescue nitrogen showed a $29 \%$ reduction in the number of pods per plant when compared with non-waterlogged control plants (Table 3). When waterlogged plants were applied with different doses of rescue nitrogen, the number of pods increased and reductions varied from $13-22 \%$. However, $\mathrm{N}_{40}$ dose performed better in pod formation under waterlogging conditions. Similarly, the grain yield decreased by $25 \%$ due to waterlogging when plants were not applied with additional nitrogen. Grain yield was comparatively better in $\mathrm{N}_{40}$ followed by $\mathrm{N}_{50}$ treatments and yield reduction was recorded 13 and $18 \%$, respectively. Akhtaruzzaman (1998) reported that $\mathrm{N}$ fertilized mungbean produced an increased number of pods per plant and seed yield in mungbean subjected to waterlogging.
Ashraf et al. (2011) advocated post-waterlogging fertilizer application to improve growth and yield of upland cotton affected by hypoxia. Foliarapplied $\mathrm{N}$ can also be effectively used in reducing the detrimental effects of waterlogging at the post-anthesis stage in winter wheat yield (Wu et al., 2014). The cause of yield increase under waterlogging conditions for rescue $\mathrm{N}$ is explained by the fact that post-waterlogging $\mathrm{N}$ application increases photosynthetic capacity by increasing leaf area index (LAI), decreasing photo-damage to PSII and leaf chlorophyll content (Florez-Velasco et al., 2015; Wu et al., $2013 \mathrm{~b}$ ). However, the method of $\mathrm{N}$ application is most important and Reed and Gordon (2005) suggested using the liquid form of $\mathrm{N}$ fertilizer, which was found to produce greater pod fresh weight than that of normal and foliar fertility treatments. 
Table 3. Pod formation and seed yield of waterlogged mungbean plant as affected by rescue $\mathrm{N}$ fertilizer

\begin{tabular}{ccccccc}
\hline Treatment & \multicolumn{2}{c}{ Pods/plants (no.) } & Relative & \multicolumn{2}{c}{ Grain yield (t/ha) } & \multirow{2}{*}{$\begin{array}{l}\text { Relative } \\
\text { grain yield }\end{array}$} \\
\cline { 2 - 3 } & Control & Waterlogging & pods/plants & Control & Waterlogging & \\
\hline $\mathrm{N}_{0}$ & 18.78 & 13.25 & $0.71 \mathrm{c}$ & 1.57 & 1.17 & $0.75 \mathrm{c}$ \\
& \pm 0.72 & \pm 0.29 & \pm 0.02 & \pm 0.02 & \pm 0.02 & \pm 0.02 \\
$\mathrm{~N}_{30}$ & 17.79 & 13.48 & $0.76 \mathrm{bc}$ & 1.53 & 1.18 & $0.77 \mathrm{c}$ \\
& \pm 0.47 & \pm 0.61 & \pm 0.02 & \pm 0.07 & \pm 0.06 & \pm 0.02 \\
$\mathrm{~N}_{40}$ & 14.30 & 12.51 & $0.88 \mathrm{a}$ & 1.32 & 1.14 & $0.87 \mathrm{a}$ \\
& \pm 0.39 & \pm 0.24 & \pm 0.04 & \pm 0.05 & \pm 0.01 & \pm 0.04 \\
$\mathrm{~N}_{50}$ & 15.60 & 12.48 & $0.80 \mathrm{~b}$ & 1.36 & 1.12 & $0.82 \mathrm{~b}$ \\
& \pm 0.35 & \pm 0.80 & \pm 0.05 & \pm 0.01 & \pm 0.04 & \pm 0.05 \\
\hline $\mathrm{LSD}$ & & & 0.040 & & & 0.060 \\
$\mathrm{CV}$ & & & 3.08 & & & 4.74 \\
\hline
\end{tabular}

Note: $\mathrm{N}_{0}$-no rescue $\mathrm{N} ; \mathrm{N}_{30}, \mathrm{~N}_{40}$ and $\mathrm{N}_{50}$ - rescue $\mathrm{N}$ at 30,40 and $50 \mathrm{~kg} \mathrm{ha}^{-1}$, respectively; Means followed by the same letter (s) are not significantly different at $\mathrm{P}<0.05$ by LSD; \pm Standard deviation.

\section{Conclusions}

The application of rescue $\mathrm{N}$ fertilizer was found to improve the growth and yield of mungbean subjected to waterlogging and this may be a valuable practice for the mungbean growing areas suffering from waterlogging. However, the recovery of plants from waterlogging injury after application of rescue $\mathrm{N}$ remarkably varied with the amount of fertilizer. Further research is needed to quantify the appropriate amount of rescue $\mathrm{N}$ fertilizer and time of its application to increase waterlogging tolerance in mungbean. Furthermore, the study is suggested to evaluate the potentiality of different methods of using $\mathrm{N}$ fertilizer during the recovery phase of waterlogged mungbean plants.

\section{Acknowledgements}

The authors wish to thank the Bangladesh Bureau of Educational Information and Statistics (BANBEIS), Ministry of Education, Government of the People's Republic of Bangladesh for providing the fund under the Higher Educational Research Program.

\section{References}

Aktaruzzaman MA. 1998. Influence of rates of nitrogen and phosphorus fertilizers on the productivity of mungbean [(Vigna radiata (L.) Wilczek.] Ph.D. thesis. Bangabandhu Sheikh Mujibur Rahman Agricultural University. Bangladesh, 1-181 pp.

Amin MR., Karim MA., Khaliq QA., Islam MR., Aktar S. 2015. Effect of nitrogen and potassium on the root growth, nutrient content and yield of mungbean (Vigna radiata $\mathrm{L}$. Wilczek) under waterlogged condition. The Agriculturists, 13(1): 6778.

Analytical Software. 2018. Statistix 10. An Analytical Software, 2105 Miller Landing Rd, Tallahassee.

Ashraf MA., Ahmad MSA., Ashraf M., AlQurainy F., Ashraf MY. 2011. Alleviation of waterlogging stress in upland cotton 
(Gossypium hirsutum L.) by exogenous application of potassium in soil and as a foliar spray. Crop Pasture Science, 62: 25-38.

BBS. 2017. Yearbook of Agricultural Statistics. Bangladesh Bureau of Statistics (BBS). 28th series.

Bhaduri D., Mandal A., Chakraborty K., Chatterjee D., Dey R. 2017. Interlinked chemical-biological processes in anoxic waterlogged soil - A review. Indian Journal of Agricultural Sciences, 87:1587-1599.

De Souza TC., Magalhães PC., Pereira FJ., De Castro EM., Parentoni SN. 2011. Morphophysiology and maize grain yield under periodic soil flooding in successive selection cycles. Acta Physiologiae Plantarum, 33:1877-1885.

Elzenga JTM., van Veen H. 2010. Waterlogging and Plant Nutrient Uptake. In: Mancuso S., Shabala S. (eds) Waterlogging Signaling and Tolerance in Plants. Springer, Berlin, Heidelberg, 23-35 pp.

Florez-Velasco N., Lopez HEB., Restrepo-Diaz H. 2015. Effects of foliar urea application on lulo (Solanum quitoense cv. septentrionale) plants grown under different waterlogging and nitrogen conditions. Scientia Horticulturae, 186:154-162.

Guo WQ., Chen BL. Liu RX., Zhou ZG. 2010b. Effects of nitrogen application rate on cotton leaf antioxidant enzyme activities and endogenous hormone contents under short-term waterlogging at flowering and boll-forming stage. Chinese Journal of Applied Ecology, 21: 53-60.

Guo W., Liu R., Zhou Z., Chen B., Xu_N. 2010a. Waterlogging of cotton calls for caution with N fertilization. Acta Agriculturae Scandinavica, 60:450-459.

Habibzadeh F., Sorooshzadeh A., Pirdashti H., Modarres-Sanavy SAM. 2013. Alleviation of waterlogging damage by foliar application of nitrogen compounds and tricyclazole in canola. Australian Journal of Crop Science, 7: 401-406.
Harris RH., Armstrong RD., Wallace AJ., Belyaeva ON. 2016. Effect of nitrogen fertiliser management on soil mineral nitrogen, nitrous oxide losses, yield and nitrogen uptake of wheat growing in waterlogging-prone soils of south-eastern Australia. Soil Research, 54: 619-33.

Hossain MA., Uddin SN. 2011. Mechanisms of waterlogging tolerance in wheat: morphological and metabolic adaptations under hypoxic or anoxia. Australian Journal Crop Science, 5: 1094- 1101.

Islam MR., Hamid A., Khaliq QA., Haque MM., Ahmed JU., Karim MA. 2010. Effects of soil flooding on roots, photosynthesis and water relations in mungbean (Vigna radiata (L.) Wilczek). Bangladesh Journal of Botany, 39: 241-243.

Jain R., Singh SP., Singh A., Singh S., Chandra A., Solomon S. 2016. Response of Foliar Application of Nitrogen Compounds on Sugarcane Grown Under Waterlogging Stress. Sugar Tech, 18:433-436.

Kaur G., Nelson KA., Motavalli PP. 2018. EarlySeason soil waterlogging and $\mathrm{N}$ fertilizer sources impacts on corn $\mathrm{N}$ uptake and apparent N recovery efficiency. Agronomy, 8: 102.

Kaur G., Zurweller BA., Nelson KA., Motavalli PP., Dudenhoeffer CJ. 2017. Soil waterlogging and nitrogen fertilizer management effects on corn and soybean yields. Agronomy Journal, 109: 97-106.

Kisaakye E., Acuna TB., Johnson P., Shabala S. 2017. Improving wheat growth and nitrogen-use efficiency under waterlogged conditions. Proceedings of the 18th Australian Society of Agronomy Conference, 24-28 September 2017, Ballarat, Australia, 1-4 pp.

Kumar P., Pal M., Joshi R., Sairam RK. 2013. Yield, growth and physiological responses of mungbean [Vigna radiata (L.) Wilczek] genotypes to waterlogging at vegetative stage. Physiol Mol Biol Plants, 19: 209-220.

Malik AI., Colmer TD., Lambers H., Setter TL., Schortemeyer M. 2002. Short-term 
waterlogging has long-term effects on the growth and physiology of wheat. New Phytologist, 153: 225-236.

McFarlane D., Glencross R. 1994. Managing waterlogging and inundation in pastures. Farmnote 79/93. Department of Agriculture, Western Australia, 1-4 pp.

Paterson J., Palta JA. 2007. Unravelling the roots of waterlogging wheat. Farming Ahead- A Technical Report, CSIRO Australia, 180:44-45.

Rasaei A., Ghobadi ME., Jalali-Honarmand S., Ghobadi M., Saeidi M. 2012. Waterlogging and its effects on nitrogen of soil and plant. Annals of Biological Research, 3:119-124.

Reed ST., Gordon GG. 2005. Flooding Influences on growth and development of bush bean under greenhouse conditions. Journal of Vegetable Science, 11:256-272.

Ren B., Zhang J., Dong S., Liu P., Zhao B., Li H. 2017. Nitrapyrin improves grain yield and nitrogen use efficiency of summer maize waterlogged in the field. Agronomy Journal, 109: 185-192.

Romheld V., Kirkby EA. 2010. Research on potassium in agriculture: Needs and prospects. Plant and Soil, 335:155-180.

Setter TL., Waters I. 2003. Review of prospects for germplasm improvement for waterlogging tolerance in wheat, barley and oats. Plant and Soil, 253:1-34.

Sigua GC., Williams M., Grabowski J., Chase C., Kongchum M. 2012. Effect of flooding duration and nitrogen fertilization on yield and protein content of three forage species. Agronomy Journal, 104: 791-798.

Singh DP., Singh BB. 2011. Breeding for tolerance to abiotic stresses in mungbean. Journal of Food Legumes, 24:83-90.

Steffens D., Hutsch BW., Eschholz T., Losak T., Schubert S. 2005. Waterlogging may inhibit plant growth primarily by nutrient deficiency rather than nutrient toxicity. Plant Soil and Environment, 51:545- 552.

Tariq M., Khaliq A., Umar M. 2001. Effect of phosphorus and potassium application on growth and yield of mungbean. On-line Journal of Biological Science, 1: 427-428.

Trought MC., Drew MC. 1980. The development of waterlogging in wheat seedlings. I. Shoot and root growth in relation to changes in the concentration of dissolved gases and solutes in the soil solution. Plant and Soil, 54: 77-94.

Wu JD., Li JC., Wei FZ., Wang CY., Zhang Y., Sun G. 2014. Effects of nitrogen spraying on the post-anthesis stage of winter wheat under waterlogging stress. Acta Physiologiae Plantarum, 36:207-216.

Wu JD., Li JC., Wang CY., Wei FZ., Zhang Y., Wu WM. 2013b. Effects of spraying foliar nitrogen on activities of key regulatory enzymes involved in protein formation in winter wheat suffered post-anthesis high temperature and waterlogging. Journal of Food, Agriculture and Environment, 11: 668-673.

Wu WM., Li JC., Chen HJ., Wang SJ., Wei FZ., Wang CY., Wang YH., Wu JD., Zhang Y. 2013a. Effects of nitrogen fertilization on chlorophyll fluorescence change in maize (Zea mays L.) under waterlogging at seedling stage. Journal of Food, Agriculture and Environment, 11: 545552.

Zaidi PH., Maniselvan P., Yadav PAK., Singh F., Sultana R., Dureja P., Singh RP., Srinivasan G. 2007. Stress adaptive change in tropical maize (Zea mays L.) under excessive moisture stress. Maydica, 52: 159-171.

Zheng W., Liu Z., Zhang M., Shi Y., Zhu Q., Sun Y. 2017. Improving crop yields, nitrogen use efficiencies, and profits by using mixtures of coated controlledreleased and uncoated urea in a wheatmaize system. Field Crops Research, 205: 106-115.

Zhou ZQ., Oosterhuis MD. 2012. Physiological mechanism of nitrogen mediating cotton (Gossypium hirsutum L.) seedlings growth under water-stress conditions. American Journal of Plant Science, 3:721-730. 